\title{
Undergraduate teaching of occupational health
}

My introduction to the diseases of occupation occurred, as did that of many students at the time, during medical school vacations. A variety of casual, unskilled jobs in industry gave us the opportunity to experience the full horrors of the work setting and to observe the health of our less privileged fellow workers. For them, their jobs represented a lifelong commitment. My undergraduate education in occupational health and safety, such as it was, was greatly reinforced when I fell from an improperly secured scaffold board and fractured my wrist.

What of more formal attempts to teach occupational health as a subject in the undergraduate curriculum?

A survey by Phoon et al who canvassed 1200 medical schools and received replies from 600 found that of these (perhaps keener) foundations, some $65 \%$ had occupational health on their compulsory curriculum (paper presented at XXII International Congress on Health, Sydney, 1987). Twenty nine per cent did not teach it at all, although some informal teaching might well have gone on disguised as respiratory medicine, dermatology, or community medicine. North American students were exposed in only $48 \%$ of schools whereas those in Oceania received tuition at a rate of $85 \%$. Hours of teaching varied between 13 (Oceania) and 51 (Latin America) with a mean tuition time of $32 \cdot 7$. As expected there is great variability in the complement of academic staff trained in occupational health, in the teaching methods (although lectures remain the favourite mode), and in the incorporation of occupational health questions into formal examinations. This despite the fact that most curricula do mention occupational medicine, usually as a part of community medicine, and imply that questions on the subject might be asked in final examinations.

Some information on the same topic was collected for the United Kingdom in 1970 by Gauvain who found that all the 20 medical schools who replied to a questionnaire gave some teaching in occupational medicine. 'Waldron had replies from 25 of 30 schools, of which only $\mathbf{1 5}$ gave formal instruction - often very little. ${ }^{2}$ A more recent survey by the faculty of occupational medicine of the Royal College of Physicians achieved a $100 \%$ response from the 27 medical schools, of whom seven provided no teaching at all and $50 \%$ little more than a few lectures on the subject. $^{3}$

Undergraduate teaching of occupational health is evidently patchily applied throughout the world. Is this right and to be expected considering variable need? Should occupational medicine be taught at the undergraduate level at all? If so, how much time should be devoted to it, who should teach it, what should the teaching objectives be, and how should it be done?

Overt occupational disease may be in decline in industrially developed countries yet it still in the United Kingdom causes deaths and disabilities at twice the rate of those caused by industrial accidents.

The incidence of occupational ill health must be much higher in developing countries. Clearly, undergraduates should be aware of the more prevalent and serious occupational diseases.

"The environment" has become a popular field of study although we probably know more about the effects of environmental change on tree growth than on human health. Medicine now has to consider this issue in an age when most disease causing premature death or disability is heavily environmentally conditioned. This has become an international problempollution, radioactive discharges, and changes in atmospheric carbon dioxide are not respecters of political boundaries. They are also difficult issues to examine but there are smaller scale models and a methodology already formulated within the occupational health disciplines. Of all environmental factors, we probably know most about the health effects of occupation and its role in the complex tissue of "work related disease." As a way of introducing the appreciation of worldwide environmental effects and how to measure, monitor, and modify them, occupational health teaching is relevant to today's medical students. In developing countries these reasons are no less important, especially as doctors are more likely to be closer to government policy makers, but in addition there is a greater toll of occupational accidents and diseases to be understood, treated, or prevented.

Perhaps the best reason for teaching occupational health to medical students is by analogy with that of 
sociology or family practice teaching. Most adults spend a third of their lives at work by which their health is affected directly (for good or ill) by working conditions and important elements of their social network established. Work in its widest sense is a major health conditioner and deserves to be studied in much the same depth as are social trends and family relations at the undergraduate level. Students really should appreciate what their patients spend their time doing when they are not being talked to by doctors and thus on their best behaviour.

One reason for occupational health not being taught extensively or consistently is curriculum pressure-competition from subjects which, however important to specialists in, say, oncology or imaging techniques, are of arguable value to those $50 \%$ of students aiming for a career in general practice where occupational problems turn up every day. Occupational health probably fails to appear because there are few occupational physicians or academics to plead its case at the undergraduate level. In the United Kingdom several consultant posts in the subject have recently been created in hospitals and this may help.

One way of imparting some of the relevant facts of clinical occupational medicine is to insert them into other areas - industrial dermatitis into dermatology, occupational cancer into oncology, rehabilitation into neurology and rheumatology, and this is much easier to do if, as is now recommended, clinical teaching is done by the team method-that is, is integrated and multidisciplinary. "Occupational ward rounds" are feasible even without patients suffering from industrial diseases.

A real problem is to get students who are already overburdened with the ever increasing load of medical knowledge considered necessary to be interested in what they often see as a "soft" subject-one that can be dispensed with now and picked up later as and when required. For this reason, lectures are unlikely to sink in and more innovative and indeed impressive methods may be needed.

"Factory visits" can be impressive-who can ever forget their first descent into a coal mine or view the patent monotony of factory assembly work without being moved? More useful, perhaps, might be a visit to a firefighter's training centre to witness the use of respirators in smoke filled rooms, measure pre- and post-pulse rates, and ponder on fitness to work. This turns a visit into a much more directive educational exercise. If there is no suitable local industry why not use the hospital itself where there are a multitude of industries going on, mostly hidden from view in kitchens, sewing rooms, boiler houses, stores, and incinerators.
Case history presentations are not difficult to make up and may be presented as detective stories with evero unfolding evidence in the form of slides and numerical? and graphic data. The American Association of Teachers of Preventive Medicine has produced many examples. Students enjoy this type of problem solving exercise and cannot easily fall asleep.

Other techniques such as role playing exercises have been tried with success. For example, members of the seminar group are given a job and job profile-worksw manager, company doctor, trades union represen- $\overrightarrow{0}$ tative, etc - and are left (with written backgroundinformation) to fight their respective corners when aw hazardous new process is brought into the factory too save it from having to close down owing to falling orders.

This type of exercise not only teaches about a hazard such as lead or isocyanates, it highlights in an: often emotional way (because of ready role identifica- $-\vec{\omega}$ tion) why individuals feel differentially threatened ando how decisions are made on outcomes.

However the material is presented and in whatever $\vec{c}$ time allowed, the undergraduate should learn some $=\frac{}{<}$ thing of:

How to take an occupational history

The distribution, recognition, management, and prevention of the major occupational diseases

What work in an industrial (or agricultural) societys is actually like

When to report occupational disease and where too look for specialist help

How to go about sensibly answering questions such $\overrightarrow{\vec{F}}$ as "is my childs lack of progress at school due to lead 3 emission from car exhaust," "could my work as amotor mechanic damage my hearing," or "should है worry about the health effects of fallout from Chernobyl."

Disability, handicap, and rehabilitation after ill ness.

Senior Lecturer in Occupational Health,

D SNASHALLำ

United Medical Schools of Guys \&

St Thomas's Hospitals,

London SE1 7EH

\section{References}

1 Gauvain S. In: Glover JR, ed. Symposium on occupational health for the undergraduate medical student. London: Society of $\sigma$ Occupational Medicine, London, 1972.

2 Waldron HA. Undergraduate training in occupational medicine. Lancet 1974;ii:277-8.

3 Harrington $M$, Seaton $A$, Philipp $R$, et al. Undergraduate $\stackrel{\mathcal{E}}{+}$ occupational health teaching in British medical schools. Journal of the Royal College of Physicians 1989;23:24-7. 